\title{
Genetic introgression between wild and stocked salmonids and the prospects for using molecular markers in population rehabilitation: the case of the Adriatic grayling (Thymallus thymallus L. 1785)
}

\author{
S Sušnik ${ }^{1,4}$, P Berrebi ${ }^{2}$, P Dovč ${ }^{1}$, MM Hansen ${ }^{3}$ and A Snoj ${ }^{1}$ \\ ${ }^{1}$ Biotechnical Faculty, Department of Animal Science, Groblje 3, SI-1230 Domžale, Slovenia; ${ }^{2}$ Laboratoire Ecosystèmes Lagunaires, UMR \\ CNRS-UM2 5119, Université Montpellier 2, cc093, 34095 Montpellier cedex 05, France; ${ }^{3}$ Department of Inland Fisheries, Danish \\ Institute for Fisheries Research, Vejlsøvej 39, DK-8600 Silkeborg, Denmark
}

\begin{abstract}
In the north Adriatic basin, a morphologically and genetically distinct lineage of grayling is found, designated as the Adriatic grayling. In Slovenia, the Adriatic grayling is restricted to the Soča river system, where it is critically endangered. The most pertinent threat is stocking with nonnative, highly divergent Sava (Danubian) drainage stock, and this activity has been going on for more than four decades. The present study was designed to characterise the genetic structure of the Adriatic grayling in Slovenia, with particular emphasis on estimating the degree of introgression with nonindigenous stocked grayling. We analysed polymorphism at 154 microsatellite loci in samples representing grayling from the Adriatic and Danubian drainage stock. A relatively high number (12) of alleles, diagnostic for the Adriatic grayling, were identified. However, a correspondence analysis based on individual multilocus genotypes also revealed that there is
\end{abstract}

no distinctive Adriatic group but rather a dispersed multitude of individuals that cannot be unambiguously distinguished from the more homogenous Danubian population. A Bayesian analysis of individual admixture coefficients confirmed this pattern and revealed extensive introgression between the Adriatic grayling and stocked grayling of Danubian origin. Average individual admixture coefficients showed that only between 50 and $60 \%$ of the original gene pools remained, and only few non-introgressed indigenous individuals could be identified. Microsatellite-based individual admixture analysis appear to be an important tool for identifying remaining non-introgressed indigenous individuals that could be used for restoring the original populations.

Heredity (2004) 93, 273-282. doi:10.1038/sj.hdy.6800500

Published online 23 June 2004

Keywords: admixture analysis; Adriatic grayling; Thymallus thymallus; microsatellites; introgression; conservation

\section{Introduction}

Gene flow from domesticated strains of fish to wild conspecifics represents a danger to the genetic integrity of indigenous populations. The family Salmonidae includes a number of culturally and economically important species that have frequently been subject to anthropogenic pressure, such as pollution, habitat destruction, commercial fishing and angling. Whereas stocking of hatchery-reared fish was previously regarded as a measure to compensate for anthropogenically induced population declines, it has become increasingly clear during the past decades that stocking with domesticated and/or non-indigenous fish represents a severe threat to indigenous populations. These mechanisms are complex, but swamping of indigenous gene pools and possible disruption of local adaptions are the main concerns (reviewed in Hindar et al, 1991; Leary et al,

Correspondence: A Snoj, Biotechnical Faculty, Department of Animal Science, Groblje 3, SI-1230 Domžale, Slovenia.

E-mail:ales.snoj@bfro.uni-lj.si

${ }^{4}$ Current address: Agricultural Institute of Slovenia, Hacquetova 17, SI-1000 Ljubljana, Slovenia.

Received 23 May 2003; accepted 7 April 2004; published online 23 June 2004
1995). Several studies, based on analysis of molecular markers, have been undertaken in order to estimate the impact of stocking with non-native individuals on the genetic composition of wild salmonid populations (eg Hindar et al, 1991). More recently, new statistical developments such as Bayesian inference of the population of origin of individuals (Pritchard et al, 2000) have significantly improved possibilities for analysing admixture between stocked and indigenous fish populations, both at the population and individual levels (Hansen et al, 2001; Koskinen et al, 2002a; Hansen, 2002). This makes it possible not only to identify introgressed and nonintrogressed indigenous populations, but also to identify introgressed and non-introgressed individuals within stocked populations, thereby providing a tool to conserve and restore remnant indigenous gene pools (Berrebi et al, 2000; Nielsen et al, 2001).

Grayling (Thymallus thymallus L. 1785, Teleostei: Salmonidae) has experienced significant population declines due to establishment of impassable weirs, habitat degradation, overharvesting (angling) and depredation by piscivorous birds (eg Meldgaard et al, 2003). In order to enhance grayling populations, rearing of local and also introduced stocking material has been undertaken in several countries, such as Finland, Sweden, 
Austria, Germany, Switzerland, Poland and Slovenia (Persat and Eppe, 1997; Eppe, 2001; Uiblein et al, 2001; Koskinen et al, 2002a; S. Pleško, personal communication). Indiscriminate releases of hatchery-reared fish into habitats originally populated with geographically confined and genetically distinct populations have occurred during recent decades. The consequences of such actions have already been described for $T$. thymallus at the molecular level using allozyme (Bouvet et al, 1990; Persat, 1996), mtDNA (Gross et al, 2001; Weiss et al, 2002) and microsatellite markers (Koskinen et al, 2002a).

Grayling is abundant in all main European drainages and inhabits the middle parts of the streams (Northcote, 1995). According to external appearance, it is a very heterogeneous species, exhibiting several geographically confined and phenotypically distinct populations (Surre et al, 1986; Broughton, 2000). The heterogeneity has been recently revealed also at the DNA level, represented by extremely high levels of intraspecific genetic divergence ( $\mathrm{F}_{\mathrm{st}}$ up to $0.74 ; P<0.001$ ), even across short geographical distances (Koskinen et al, 2002b).

In the north Adriatic basin (the river systems in northeastern Italy and western Slovenia), a morphologically and genetically distinct lineage of grayling has been described, designated as the Adriatic grayling (Sušnik et al, 2001). Although phenotypically distinct and considered highly threatened (Voljc and Ocvirk, 1982), the Adriatic grayling has never received official conservation status. Besides unspecific threats, such as general pollution, overfishing and depredation by piscivorous birds, the Adriatic grayling has been significantly endangered by stocking activities involving non-indigenous Danubian (the River Sava) stocks, which has been reared in local facilities. This strain has been stocked intensively into the Soča river system for more than four decades (Bertok and Budihna, 1999). The Adriatic grayling was abundant in the Soča river system before 1960. It was characterised by several morphological features (eg dark grey coloration, pronounced shape of the hump, lack of black spots and magenta stain; D Jesenšek, personal communication; for details, see Sabbadini, 2000), making it very different from its trans-Alpine relatives. Its morphometric and meristic characters were precisely described and compared to several Danubian populations of former Yugoslavia (Janković, 1960). According to meristic data (the number of gill rakers, dorsal rays, pyloric caeca, etc.), the Adriatic grayling differed significantly from all the Danubian populations analysed, whereas morphometric characters were less indicative (Janković, 1960).

As inferred from mtDNA data (Sušnik et al, 2001; Weiss et al, 2002) and preliminary results of microsatellite analysis (Snoj et al, 1999; Sušnik et al, 1999a, b, 2000), the distinctness of the Adriatic grayling has been confirmed also at the genetic level. The results of phylogenetic analysis based on mtDNA indicated an ancient monophyletic origin of the Adriatic grayling, probably isolated from other grayling populations since the late Miocene. These findings, together with the phenotypic uniqueness, implied complete genetic separation of the Adriatic grayling populations from other European populations, suggesting that it should be highly prioritised for conservation. However, in the present Adriatic population, mtDNA haplotypes of Danubian origin were found, suggesting a considerable amount of recent gene flow between the two phylogeographic lineages (Sušnik et al, 2001). This finding reflected the consequence of stocking with allochthonous grayling and indicated a strong negative impact on the extant native population. Nevertheless, this approach could not reveal the degree of genetic interactions between native and introduced population. In this context, microsatellite markers have higher resolution and have already been used for studying population structuring and assessing genetic differences between contemporary wild and introduced populations (eg Poteaux et al, 1999; Hansen et al, 2001; Koskinen et al, 2002a).

The present study, based on analysis of 15 microsatellite loci, was designed to characterise the genetic structure of grayling population in the Soča river system in order to (i) estimate the degree of introgression (admixture) with non-indigenous stocks, and (ii) explore the possibilities for using molecular markers to identify non-introgressed remains of indigenous Adriatic grayling for future management and supportive breeding.

\section{Materials and methods}

\section{Sampling}

Grayling were sampled in the Adriatic (82 individuals) and Danube basin (50 individuals; Table 1 and Figure 1). The Adriatic grayling was represented by four subpopulations from Slovenia (the rivers Soča-main basin, Tolminka, Koritnica; all from the Soča river system) and Italy (the River Sessia, a part of the Pô river system). In addition, three populations were sampled from the Danubian basin within Slovenia (the rivers Sava, Obrh, Unec; all from the Sava river system). All Slovenian populations have been managed with hatchery-reared strains, derived from the Sava river system, and the only presumably wild, non-stocked Adriatic subpopulation included in the analysis was from the River Sessia (Italy).

Table 1 Details of samples, sample size, year of sampling and population designation on the map (Figure 1)

\begin{tabular}{llllcc}
\hline River basin & River system & Location & $\mathrm{N}$ & Year of sampling & Designation on the map \\
\hline Danubian & Sava & Sava (SI) & 22 & 1998 & 1 \\
& & Obrh (SI) & 18 & 1999 & 2 \\
Adriatic & Soča & Unec (SI) & 10 & 1999 & 3 \\
& & Soča (SI) & 22 & 1999 & 4 \\
& & Tolminka (SI) & 34 & 1997 & 5 \\
& Pô & Koritnica (SI) & 14 & 1999 & 6 \\
\hline
\end{tabular}

SI: Slovenia; I: Italy. 


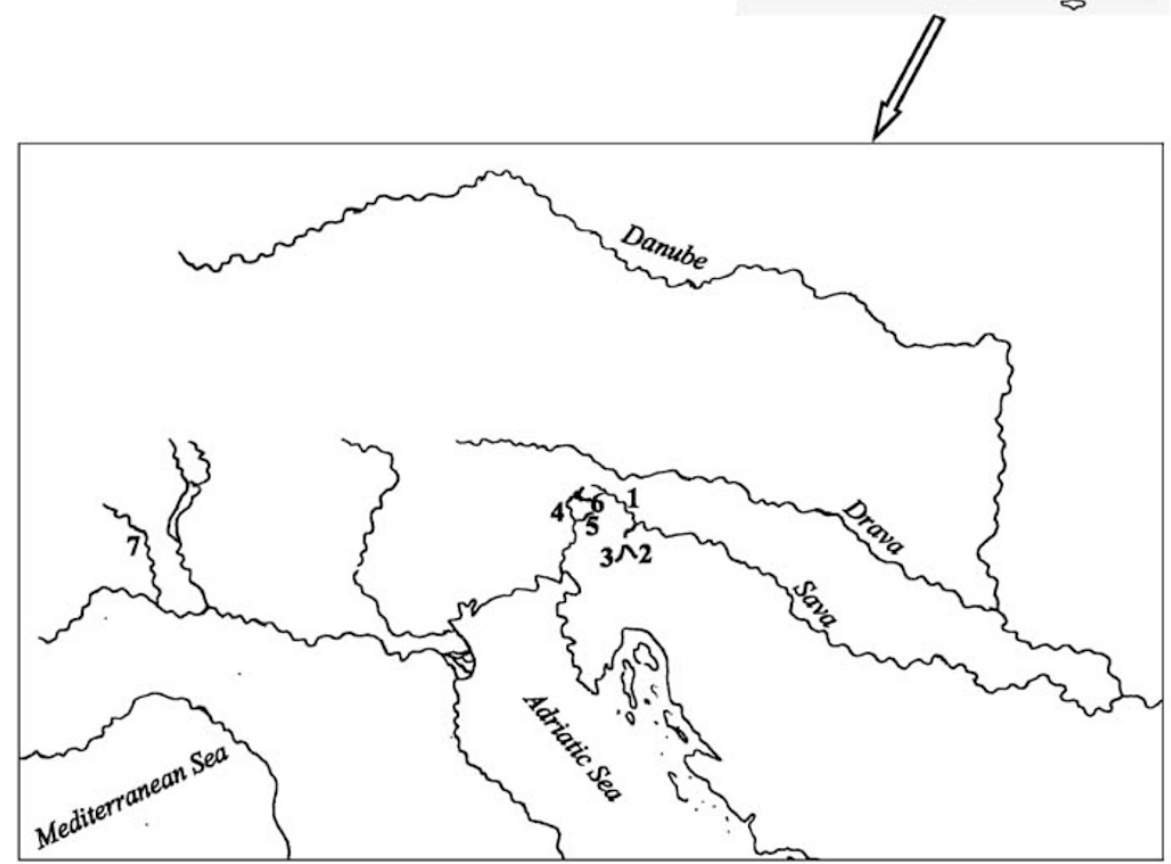

Figure 1 Sampling locations of $T$. thymallus. Names and locations of sampling sites are listed in Table 1.

Blood or fin tissue samples were taken from anaesthetised animals and conserved at $-20^{\circ} \mathrm{C}$ or in $96 \%$ ethanol, respectively.

\section{DNA extraction and genetic analysis}

Genomic DNA was isolated from nucleated red blood cells or fin tissue according to a protocol using $\mathrm{NaCl}$ protein extraction, followed by DNA ethanol precipitation (Medrano et al, 1990).

Microsatellite polymorphism was analysed at 15 loci. In addition to 13 microsatellite loci already described (BFRO004 (Snoj et al, 1999), BFRO005 to BFRO009 (Sušnik et al, 1999a), BFRO014 to BFRO018 (Sušnik et al, 1999b), BFRO010 and BFRO011 (Sušnik et al, 2000)), an additional two loci were analysed (BFRO012: (CA) 17 , Acc. No. AF130411, F: 5'-TTCTTAGTGATGAGGGTGGG-3', R: 5'-ACTTTGTCTGTGGGTGGATG-3', $T_{\mathrm{a}}=60^{\circ} \mathrm{C} ; \mathrm{BFRO013:}$ $\left(\mathrm{GATT}_{7}\right.$, Acc. No. AF151370, F: 5'-CATTGCTTGCTCTT TGGGGT-3', R: 5'-CCCGTTGATTATTTTGTTTCCA-3', $T_{\mathrm{a}}=60^{\circ} \mathrm{C}$ ). All microsatellite loci were isolated and characterised as described previously (Sušnik et al, 1999a).

PCR amplification and genotyping of microsatellites were conducted according to already published proto- cols (Snoj et al, 1999; Sušnik et al, 1999a, b, 2000). A total volume of $10 \mu \mathrm{l}$ of the reaction mix contained $0.5 \mu \mathrm{M}$ of each primer, $0.2 \mathrm{mM} \mathrm{dNTP}, 1.5 \mathrm{mM} \mathrm{MgCl}_{2}, 1 \times \mathrm{PCR}$ buffer, $0.5 \mathrm{U}$ of Taq polymerase (PE Applied Biosystems) and $50 \mathrm{ng}$ of genomic DNA. Loci were amplified using the PCR, with a profile of initial denaturation $\left(95^{\circ} \mathrm{C}\right.$, $3 \mathrm{~min})$, followed by 30 cycles of strand denaturation $\left(94^{\circ} \mathrm{C}, 45 \mathrm{~s}\right)$, primer annealing $\left(55\right.$ or $\left.60^{\circ} \mathrm{C}, 15 \mathrm{~s}\right)$ and DNA extension $\left(72^{\circ} \mathrm{C}, 5 \mathrm{~s}\right)$, in the $\mathrm{MJ}$ research PTC-100 Thermal cycler. Aliquots of fluorescently labelled amplified DNA were mixed with formamide and GENESCAN-350 (TAMRA) Size Standard (PE Applied Biosystems) and genotyped on the ABI Prism 310 Genetic Analyser using the GeneScan ${ }^{\mathrm{TM}}$ Analysis Software 2.1.

\section{Data analysis}

Most population genetic statistics were computed using the GENETIX (Belkhir and Borsa, 1998) and STRUCTURE software (Pritchard et al, 2000).

The statistical analysis was performed in five steps:

(1) Genetic diversity. Genetic diversity within populations was evaluated by computing allele frequencies and observed and unbiased expected heterozygosity. The program FSTAT (Goudet, 2001) was used for calculating allelic richness. 
(2) $\mathrm{F}_{\text {is }}$ and panmixia. F-statistics were estimated using the estimators of Weir and Cockerham (1984). To test for departures from Hardy-Weinberg equilibrium due to heterozygote deficiencies, alleles were permuted among individuals within samples, and the significance was assessed from the number of times the $F_{\text {is }}$ values of the permuted samples exceeded $F_{\text {is }}$ in the actual sample.

(3) $\mathrm{F}_{\mathrm{st}}$. Genetic differentiation between populations was tested by permuting individuals between samples and by computing $\theta$ ( $\mathrm{F}_{\mathrm{st}}$ estimator) for each matrix.

All tests were conducted using 10000 permutations. Sequential Bonferroni corrections were performed for simultaneous multiple tests (Rice, 1989).

(4) Multidimensional analyses. Factorial correspondence analyses (CA) were also conducted using GENETIX. In the analysis, individuals are first coded according to the presence of the different alleles with values 0 (does not possess the allele), 1 (heterozygote), 2 (homozygote for the allele). Then, composite axes (where each variable contributes differently to the global inertia) that optimise the differences between the analysed individuals are produced.

(5) Individual admixture coefficients (ie the proportion of an individual's genome derived from one or the other population) and the numbers of populations represented by the samples were estimated using STRUCTURE (Pritchard et al, 2000), a Bayesian, Markov chain Monte Carlo (MCMC)-based approach that uses model-based clustering for partitioning all individuals into groups. First, we estimated the number of populations represented by the samples. This was performed separately for all stocked populations, Soča-main basin, Tolminka and Koritnica, along with the samples representing the stocked fish. For instance, in the case of River Soča-main basin, all individuals from this sample were pooled with the individuals from the stocking populations, that is, Sava, Obrh and Unec. Next, the likelihood of the data was estimated assuming a model where the sampled individuals represented from one to five populations. Finally, the relative probability for each number of populations was calculated, as described in Pritchard et al (2000). For these runs of STRUCTURE, we used a burn-in period of 200000 steps followed by 1000000 MCMC replicates. In all cases, the probability of the presence of two populations was virtually one. Based on the assignment of individuals, it was apparent that all individuals in the stocking populations, Sava, Obrh and Unec, corresponded to one single population, whereas the individuals in the stocked populations corresponded to a mixture between stocked individuals and second populations, representing the indigenous gene pool.

We then proceeded to the next step and estimated individual admixture coefficients and their $90 \%$ probability intervals in individuals from the stocked populations, assuming a model with two populations. We forced the model to consider all Sava, Obrh and Unec individuals as representing one population and being non-admixed, whereas no prior population information was used for individuals from the stocked populations. We used a burn-in period of 50000 steps and then proceeded with 200000 MCMC steps.

Finally, we estimated population level admixture by calculating the mean of the individual admixture coefficients.

\section{Results}

\section{Polymorphism}

Analyses of all the loci revealed moderate polymorphism ranging from a minimum of two alleles per locus (BFRO007) to a maximum of 10 alleles per locus (BFRO008) (Table 2). A total of 30 alleles (10 rare alleles) were population specific; 16 of them were found only in the Sessia population showing the relative isolation between the Pô and Soča basins; 42 alleles differentiated the Adriatic populations from the Danubian ones (Table 2).

The observed heterozygosity over all loci varied from 0.28 in Sessia to 0.58 in the Koritnica population (Table 2). The observed and expected average heterozygosities in Slovenian populations were higher in all three subpopulations of the Soča river system than in the Danubian populations. Sample sizes do not seem to influence drastically the apparent levels of polymorphism: one Danubian population (from the River Unec), sampled with less individuals $(N=10)$, exhibits approximately the same level of polymorphism $\left(H_{\mathrm{obs}}=0.36\right)$ as the other two Danubian populations $\left(H_{\mathrm{obs}}=0.32,0.31 ; N=22,18\right.$; Table 3).

\section{Genetic relationships among populations}

$\mathrm{F}_{\mathrm{st}}$ : Strong genetic differentiation was observed among populations with an overall $\mathrm{F}_{\text {st }}$ value of $0.2325(P<0.01)$. Furthermore, pairwise $F_{\text {st }}$ values were in most cases significant, with the exception of geographically proximate population pairs from the same river systems (Obrh-Unec, Tolminka-Soča, Koritnica-Soča, Koritnica-Tolminka) (Table 4). Pairwise $\mathrm{F}_{\text {st }}$ values were lower between populations from the Soča river system and the Sava populations as compared to pairwise values between the Soča populations and the nonstocked Adriatic population from the River Sessia. We assume that this phenomenon is a reflection of introgression of Sava grayling into the gene pools of the Soča river populations, as further evidenced by the admixture analyses (see below).

Correspondence analysis: Most of the information on population structuring is concentrated in the first axis (inertia: 0.5013) of the global CA (data not shown), partitioning samples of Danubian and Adriatic origin. Among Slovenian samples, Danubian populations represent a very homogenous group, from which individuals sampled in the Soča river system are distributed towards positive values of the first axis, that is, towards Sessia samples. However, the Sessia individuals are separated from the Soča ones, showing a limited degree of differentiation between both groups.

Considering a CA based only on Slovenian populations, there was a partial structuring along the first axis (horizontal inertia of 0.29; Figure 2). The following axes have much lower inertia, indicating a very limited role in the discrimination among individuals (axis 2: 0.08; axis 3: 0.06). Individuals within the Danubian and Adriatic populations did not group according to their geographic origin (Figure 2). Instead, all individuals from three Danubian populations grouped together on the negative side of the first axis, whereas individuals from the Soča river system were placed continuously from the negative 
Table 2 Number of alleles, allele richness, and expected and observed heterozygosity at 15 analysed microsatellite loci in seven grayling populations

\begin{tabular}{|c|c|c|c|c|c|c|c|c|}
\hline \multirow[t]{2}{*}{ Locus } & \multicolumn{8}{|c|}{ Population } \\
\hline & Sava & Obrh & Unec & Soča & Tolminka & Koritnica & Sessia & All \\
\hline \multicolumn{9}{|l|}{ BFRO004 } \\
\hline Sample size & 22 & 18 & 10 & 22 & 34 & 14 & 12 & 132 \\
\hline No. of alleles & 2 & 2 & 2 & 3 & 3 & 3 & 2 & 3 \\
\hline Allelic richness & 1.847 & 1.999 & 2.000 & 2.999 & 2.761 & 2.926 & 2.000 & 2.941 \\
\hline$H_{\exp }$ & 0.127 & 0.313 & 0.480 & 0.613 & 0.481 & 0.564 & 0.486 & \\
\hline$H_{\mathrm{obs}}$ & 0.136 & 0.389 & 0.800 & 0.682 & 0.382 & 0.214 & 0.500 & \\
\hline \multicolumn{9}{|l|}{ BFRO005 } \\
\hline Sample size & 22 & 18 & 10 & 22 & 34 & 14 & 12 & 132 \\
\hline No. of alleles & 5 & 3 & 3 & 3 & 7 & 4 & 1 & 8 \\
\hline Allelic richness & 3.285 & 2.525 & 3.000 & 2.847 & 4.615 & 3.711 & 1.000 & 3.891 \\
\hline$H_{\exp }$ & 0.281 & 0.245 & 0.405 & 0.559 & 0.653 & 0.640 & 0.000 & \\
\hline$H_{\mathrm{obs}}$ & 0.227 & 0.278 & 0.500 & 0.364 & 0.529 & 0.714 & 0.000 & \\
\hline \multicolumn{9}{|l|}{ BFRO006 } \\
\hline Sample size & 22 & 18 & 10 & 22 & 34 & 14 & 12 & 132 \\
\hline No. of alleles & 1 & 2 & 2 & 3 & 3 & 2 & 3 & 5 \\
\hline Allelic richness & 1.000 & 1.810 & 2.000 & 2.847 & 2.924 & 2.000 & 2.812 & 2.925 \\
\hline$H_{\exp }$ & 0.000 & 0.105 & 0.255 & 0.559 & 0.586 & 0.477 & 0.226 & \\
\hline$H_{\mathrm{obs}}$ & 0.000 & 0.111 & 0.300 & 0.591 & 0.471 & 0.784 & 0.250 & \\
\hline \multicolumn{9}{|l|}{ BFRO007 } \\
\hline Sample size & 22 & 18 & 10 & 22 & 34 & 14 & 12 & 132 \\
\hline No. of alleles & 1 & 1 & 1 & 2 & 2 & 2 & 1 & 2 \\
\hline Allelic richness & 1.000 & 1.000 & 1.000 & 2.000 & 2.000 & 2.000 & 1.000 & 1.999 \\
\hline$H_{\exp }$ & 0.000 & 0.000 & 0.000 & 0.449 & 0.415 & 0.500 & 0.000 & \\
\hline$H_{\mathrm{obs}}$ & 0.000 & 0.000 & 0.000 & 0.500 & 0.471 & 0.429 & 0.000 & \\
\hline \multicolumn{9}{|l|}{ BFRO008 } \\
\hline Sample size & 22 & 18 & 10 & 22 & 34 & 14 & 12 & 132 \\
\hline No. of alleles & 5 & 4 & 2 & 4 & 7 & 5 & 4 & 10 \\
\hline Allelic richness & 4.442 & 3.466 & 2.000 & 3.706 & 5.186 & 4.637 & 4.000 & 6.001 \\
\hline$H_{\exp }$ & 0.723 & 0.411 & 0.420 & 0.654 & 0.667 & 0.661 & 0.691 & \\
\hline$H_{\mathrm{obs}}$ & 0.682 & 0.278 & 0.400 & 0.500 & 0.618 & 0.571 & 0.750 & \\
\hline \multicolumn{9}{|l|}{ BFRO009 } \\
\hline Sample size & 22 & 18 & 10 & 22 & 34 & 14 & 12 & 132 \\
\hline No. of alleles & 1 & 1 & 1 & 2 & 2 & 2 & 3 & 4 \\
\hline Allelic richness & 1.000 & 1.000 & 1.000 & 2.000 & 2.000 & 2.000 & 3.000 & 2.962 \\
\hline$H_{\text {exp }}$ & 0.000 & 0.000 & 0.000 & 0.496 & 0.448 & 0.477 & 0.642 & \\
\hline$H_{\mathrm{obs}}$ & 0.000 & 0.000 & 0.000 & 0.546 & 0.382 & 0.786 & 0.833 & \\
\hline \multicolumn{9}{|l|}{ BFRO010 } \\
\hline Sample size & 22 & 18 & 10 & 22 & 34 & 14 & 12 & 132 \\
\hline No. of alleles & 3 & 2 & 2 & 3 & 4 & 3 & 3 & 7 \\
\hline Allelic richness & 2.843 & 2.000 & 2.000 & 2.999 & 3.501 & 3.000 & 2.833 & 4.428 \\
\hline$H_{\exp }$ & 0.399 & 0.494 & 0.485 & 0.633 & 0.649 & 0.640 & 0.392 & \\
\hline$H_{\mathrm{obs}}$ & 0.364 & 0.667 & 0.700 & 0.773 & 0.647 & 0.714 & 0.500 & \\
\hline \multicolumn{9}{|l|}{ BFRO011 } \\
\hline Sample size & 22 & 18 & 10 & 22 & 34 & 14 & 12 & 132 \\
\hline No. of alleles & 2 & 2 & 2 & 4 & 4 & 3 & 3 & 7 \\
\hline Allelic richness & 1.998 & 2.000 & 2.000 & 3.376 & 3.429 & 2.983 & 2.978 & 4.241 \\
\hline$H_{\exp }$ & 0.325 & 0.475 & 0.180 & 0.567 & 0.573 & 0.574 & 0.403 & \\
\hline$H_{\mathrm{obs}}$ & 0.318 & 0.556 & 0.200 & 0.591 & 0.529 & 0.643 & 0.333 & \\
\hline \multicolumn{9}{|l|}{ BFRO012 } \\
\hline Sample size & 22 & 18 & 10 & 22 & 34 & 14 & 12 & 132 \\
\hline No. of alleles & 4 & 2 & 1 & 3 & 2 & 2 & 1 & 5 \\
\hline Allelic richness & 2.890 & 1.969 & 1.000 & 1.909 & 1.761 & 1.983 & 1.000 & 1.997 \\
\hline$H_{\exp }$ & 0.311 & 0.198 & 0.000 & 0.088 & 0.111 & 0.191 & 0.000 & \\
\hline$H_{\mathrm{obs}}$ & 0.273 & 0.222 & 0.000 & 0.091 & 0.118 & 0.214 & 0.000 & \\
\hline \multicolumn{9}{|l|}{ BFRO013 } \\
\hline Sample size & 22 & 18 & 10 & 22 & 34 & 14 & 12 & 132 \\
\hline No. of alleles & 3 & 1 & 1 & 3 & 4 & 3 & 1 & 4 \\
\hline Allelic richness & 2.454 & 1.000 & 1.000 & 2.455 & 3.671 & 2.926 & 1.000 & 3.200 \\
\hline$H_{\text {exp }}$ & 0.447 & 0.000 & 0.000 & 0.478 & 0.624 & 0.554 & 0.000 & \\
\hline$H_{\mathrm{obs}}$ & 0.591 & 0.000 & 0.000 & 0.409 & 0.559 & 0.571 & 0.000 & \\
\hline
\end{tabular}


Table 2 Continued

\begin{tabular}{|c|c|c|c|c|c|c|c|c|}
\hline \multirow[t]{2}{*}{ Locus } & \multicolumn{8}{|c|}{ Population } \\
\hline & Sava & Obrh & Unec & Soča & Tolminka & Koritnica & Sessia & All \\
\hline \multicolumn{9}{|l|}{ BFRO014 } \\
\hline Sample size & 21 & 18 & 10 & 22 & 34 & 14 & 12 & 131 \\
\hline No. of alleles & 2 & 2 & 2 & 3 & 4 & 3 & 1 & 4 \\
\hline Allelic richness & 1.935 & 1.922 & 2.000 & 2.708 & 3.243 & 2.926 & 1.000 & 2.940 \\
\hline$H_{\exp }$ & 0.172 & 0.153 & 0.375 & 0.505 & 0.597 & 0.564 & 0.000 & \\
\hline$H_{\text {obs }}$ & 0.191 & 0.056 & 0.500 & 0.682 & 0.500 & 0.643 & 0.000 & \\
\hline \multicolumn{9}{|l|}{ BFRO015 } \\
\hline Sample size & 22 & 18 & 10 & 22 & 34 & 14 & 12 & 132 \\
\hline No. of alleles & 4 & 4 & 3 & 5 & 6 & 4 & 2 & 8 \\
\hline Allelic richness & 3.453 & 3.810 & 3.000 & 4.223 & 5.489 & 3.979 & 2.000 & 5.829 \\
\hline$H_{\exp }$ & 0.633 & 0.699 & 0.645 & 0.643 & 0.774 & 0.686 & 0.330 & \\
\hline$H_{\mathrm{obs}}$ & 0.773 & 0.833 & 0.600 & 0.626 & 0.735 & 0.786 & 0.417 & \\
\hline \multicolumn{9}{|l|}{ BFRO016 } \\
\hline Sample size & 22 & 18 & 10 & 22 & 34 & 14 & 12 & 132 \\
\hline No. of alleles & 3 & 3 & 3 & 4 & 5 & 4 & 4 & 6 \\
\hline Allelic richness & 2.998 & 3.000 & 3.000 & 3.961 & 4.154 & 3.983 & 3.645 & 4.383 \\
\hline$H_{\exp }$ & 0.629 & 0.648 & 0.655 & 0.724 & 0.689 & 0.707 & 0.295 & \\
\hline$H_{\mathrm{obs}}$ & 0.591 & 0.556 & 0.700 & 0.773 & 0.676 & 0.643 & 0.250 & \\
\hline \multicolumn{9}{|l|}{ BFRO017 } \\
\hline Sample size & 22 & 18 & 10 & 22 & 34 & 14 & 12 & 132 \\
\hline No. of alleles & 1 & 1 & 1 & 2 & 2 & 2 & 1 & 2 \\
\hline Allelic richness & 1.000 & 1.000 & 1.000 & 2.000 & 2.000 & 2.000 & 1.000 & 1.985 \\
\hline$H_{\exp }$ & 0.000 & 0.000 & 0.000 & 0.375 & 0.484 & 0.436 & 0.000 & \\
\hline$H_{\text {obs }}$ & 0.000 & 0.000 & 0.000 & 0.318 & 0.588 & 0.500 & 0.000 & \\
\hline \multicolumn{9}{|l|}{ BFRO018 } \\
\hline Sample size & 22 & 18 & 10 & 22 & 34 & 14 & 12 & 132 \\
\hline No. of alleles & 4 & 3 & 3 & 4 & 4 & 4 & 3 & 6 \\
\hline Allelic richness & 3.708 & 2.969 & 3.000 & 3.942 & 3.892 & 3.713 & 3.000 & 4.640 \\
\hline$H_{\exp }$ & 0.682 & 0.554 & 0.635 & 0.681 & 0.607 & 0.566 & 0.569 & \\
\hline$H_{\mathrm{obs}}$ & 0.591 & 0.667 & 0.700 & 0.591 & 0.618 & 0.429 & 0.333 & \\
\hline \multicolumn{9}{|c|}{ Average for all samples } \\
\hline$H_{\exp }$ & 0.321 & 0.292 & 0.302 & 0.554 & 0.562 & 0.554 & 0.271 & \\
\hline$H_{\mathrm{obs}}$ & 0.321 & 0.314 & 0.361 & 0.503 & 0.523 & 0.580 & 0.286 & \\
\hline
\end{tabular}

Table $3 \mathrm{~F}_{\text {is, }}$ linkage disequilibrium and estimates of population admixture coefficients, that is, the proportion of indigenous gene pool, estimated using STRUCTURE (Pritchard et al, 2000)

\begin{tabular}{|c|c|c|c|c|c|c|}
\hline \multirow[t]{2}{*}{ Population } & \multicolumn{2}{|c|}{$F_{i s}$} & \multicolumn{3}{|c|}{ Significant linkage disequilibrium } & \multirow[t]{2}{*}{ Admixture coefficient } \\
\hline & $\mathrm{f}$ & Significance & * & $* *$ & $* * *$ & \\
\hline Sava & 0.02273 & NS (NS) & $2(1)$ & - & - & \\
\hline Obrh & -0.04519 & NS (NS) & $1(1)$ & - & - & \\
\hline Unec & -0.13684 & * (NS) & $1(1)$ & - & - & \\
\hline Soča & 0.09843 & $* *(*)$ & $14(-)$ & $4(-)$ & $3(3)$ & 0.509 \\
\hline Tolminka & 0.07857 & $* *(*)$ & $11(-)$ & $1(1)$ & $1(1)$ & 0.549 \\
\hline Koritnica & -0.01223 & NS (NS) & $7(1)$ & $4(1)$ & - & 0.570 \\
\hline Sessia & 0.01079 & NS (NS) & - & - & $1(1)$ & \\
\hline
\end{tabular}

Significance after application of sequential Bonferroni corrections is given in parentheses (NS: nonsignificant; *: significant at 0.05 level; **: significant at 0.01 level; ${ }^{* * *}$ : significant at 0.001 level).

side (Danubian group) to positive side of this axis. Some of these individuals were actually positioned among the Danubian group (Figure 2). All together, this suggests that the individuals of Danubian origin form a homogenous group, whereas there are indications of significant introgression within the Adriatic samples.
In order to estimate the possible influence of the rare alleles on individual distribution, we excluded alleles with frequencies that remained at $5 \%$ or less across all populations. Individual distribution did not change (data not shown), indicating limited influence of the rare alleles. However, the distribution of individuals from the 
Table 4 Pairwise $\mathrm{F}_{\mathrm{st}}$ values (above main diagonal) and their significance (in \%; below main diagonal), based on 10000 permutations

\begin{tabular}{|c|c|c|c|c|c|c|c|}
\hline & Sava & Obrh & Unec & Soča & Tolminka & Koritnica & Sessia \\
\hline Sava & & 0.059 & 0.068 & 0.175 & 0.191 & 0.239 & 0.638 \\
\hline Obrh & 0.0 & & 0.022 & 0.160 & 0.204 & 0.254 & 0.656 \\
\hline Unec & 0.0 & 6.3 & & 0.130 & 0.177 & 0.218 & 0.644 \\
\hline Soča & 0.0 & 0.0 & 0.0 & & 0.011 & 0.010 & 0.380 \\
\hline Tolminka & 0.0 & 0.0 & 0.0 & 7.5 & & 0.001 & 0.362 \\
\hline Koritnica & 0.0 & 0.0 & 0.0 & 16.3 & 38.5 & & 0.375 \\
\hline Sessia & 0.0 & 0.0 & 0.0 & 0.0 & 0.0 & 0.0 & \\
\hline
\end{tabular}

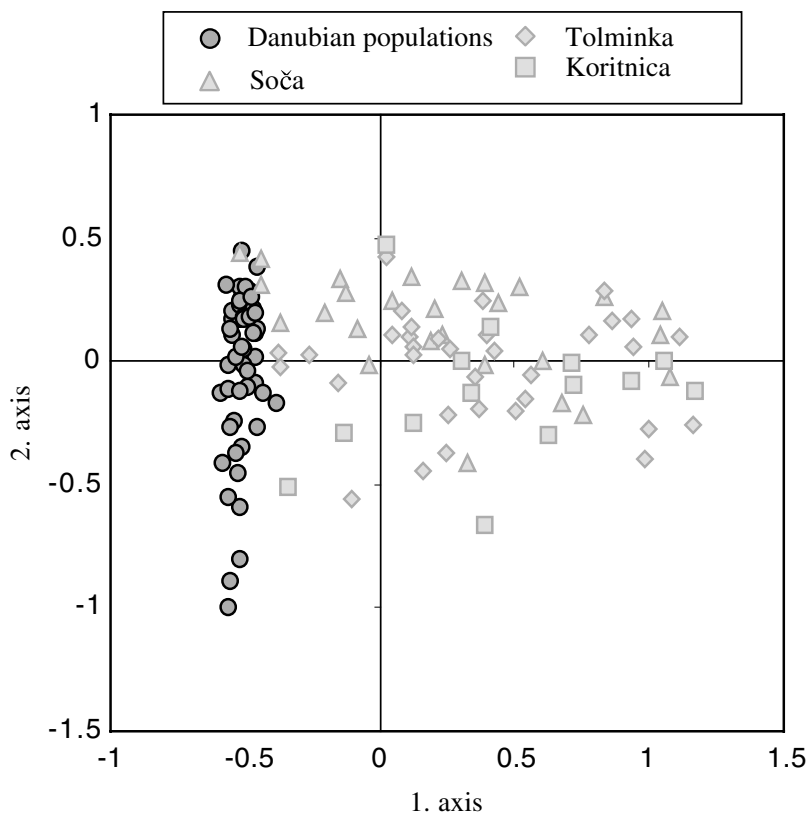

Figure 2 Diagram showing the genetic relationships among T. thymallus individuals from the Danubian and Adriatic river basins in Slovenia, based on CA.

Soča river system was highly influenced by the presence of characteristic alleles at 12 loci, which were absent in the Danube populations.

\section{Admixture analysis}

For visualising individual admixture coefficients, $q$, in samples from the Adriatic river system, we ranked individual values from lowest to highest and plotted rank versus individual $q$ values including $90 \%$ probability intervals (Figure 3 ). A $q$ value of 0 corresponds to an individual of purely exogenous origin, whereas a value of 1 is a pure indigenous individual. The bars denote $90 \%$ probability intervals. The distribution of $q$ values in all three populations showed very similar patterns. The vast majority of individuals were introgressed with some individuals of fully exogenous origin. The $q$ values ranged from 0.111 to 0.885 (three individuals with values $>0.8$ ) in River Soča-main basin, from 0.169 to 0.852 (two individuals with values $>0.8$ ) in Tolminka and from 0.197 to 0.857 (two individuals with values $>0.8$ ) in River Koritnica (Figure 3) subpopulation.

The estimates of population level admixture suggest that Danubian strain of grayling has contributed significantly to the gene pools of Adriatic grayling. Thus, the population in the River Soča-main basin retained on

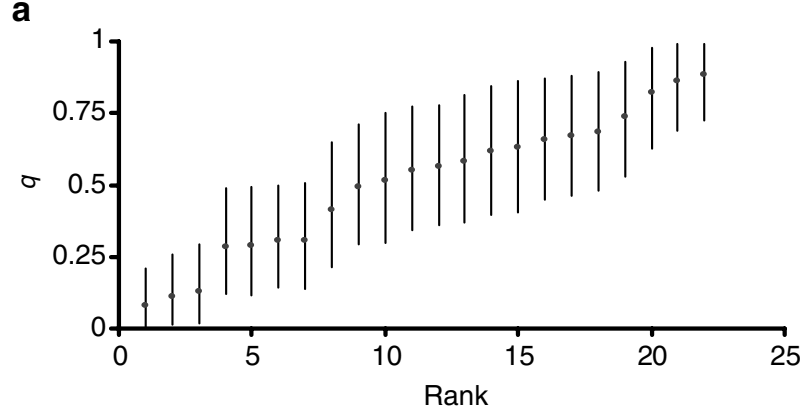

b
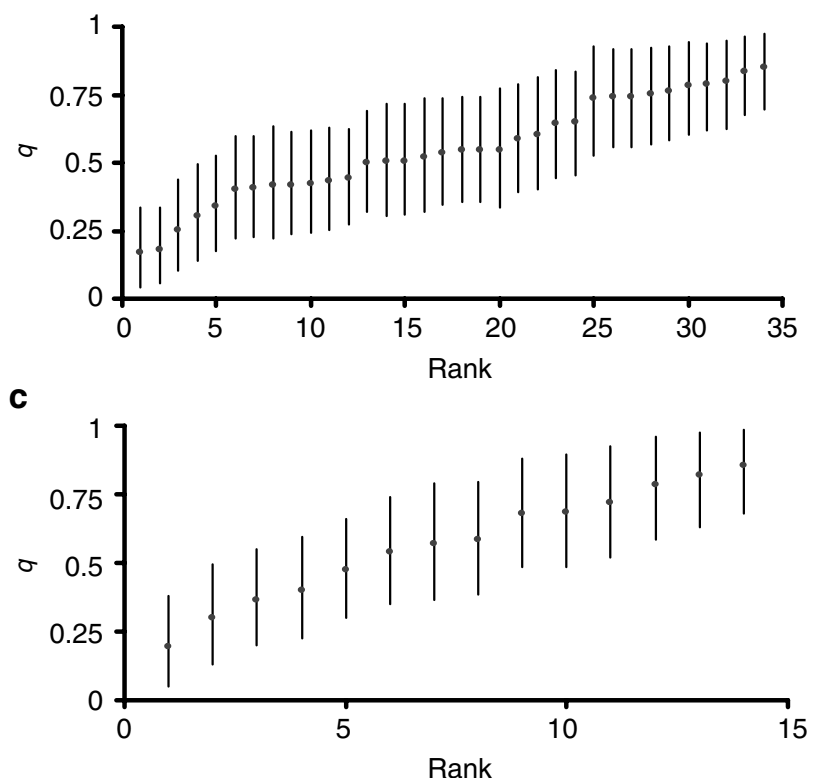

Figure 3 Plots of individual admixture coefficient $(q)$, including their $90 \%$ probability limits for individuals from (a) River Soča, (b) River Tolminka and (c) River Koritnica. A $q$ value of 0 denotes purely exogenous (Danubian) origin, whereas a value of 1 is a pure indigenous (Adriatic) individual.

average only $0.509 \%$ of its indigenous gene pool, whereas the other two populations exhibited slightly lower levels of introgression (Table 3).

\section{Discussion}

Grayling population structure in the Adriatic drainage On the basis of our analysis of microsatellite DNA polymorphism, it is obvious that grayling inhabiting all three rivers of the Soča basin studied showed considerable intrapopulation genetic heterogeneity. This was 
demonstrated by population genetic parameters such as departure from Hardy-Weinberg equilibrium and positive $F_{\text {is }}$ values. This implies that grayling in the Soča river system consist of a mixture of two populations, where panmixia has not yet been reached. Taking into account that the Soča river system has been intensively stocked with grayling from the River Sava (Danube) for more than 40 years, it must be considered certain that the genetic heterogeneity is the result of admixture of the indigenous Adriatic grayling and stocked grayling from the Danube basin. The CA based on individual multilocus genotypes provides further evidence for population structure inconsistency of grayling from the Soča drainage. The analysis reveals that there is no distinctive group of the Adriatic grayling on the graph but rather a dispersed multitude of individuals that cannot be unambiguously distinguished from the homogenous Danubian population (Figure 2). Nevertheless, individuals from the Soča river system also shared alleles at eight loci with individuals from the River Sessia. These common alleles have never been found in the Danubian populations and could thus be considered as the 'Adriatic alleles'. This allele sharing confirms the monophyletic origin of grayling from the rivers Sessia and Soča, and their distinctness from the Danubian lineage, which has been shown on the basis of mtDNA analysis (Sušnik et al, 2001).

In spite of documented stocking in most of the populations analysed, the high overall $F_{\text {st }}$ value (0. 2325, $P<0.001)$ still indicates strong differentiation among populations. On the other hand, intrapopulation variability was rather low, as observed previously in other grayling populations. This low variability has been ascribed to the life history characteristics of grayling (Koskinen et al, 2002b). The only exception to this general finding is the observation of high intrapopulation variability in grayling populations from Bavaria, probably as a consequence of stocking activity (Gross et al, 2001).

\section{Introgression}

Stocking of grayling of the Danubian origin from the Sava river system into the Soča river system, inhabited by the Adriatic grayling, has taken place since 1960 (Bertok and Budihna, 1999), even though it has been reduced in the last few years. The individual admixture analyses provided clear evidence that this has led to strong introgression by the Danubian stock of grayling into the Adriatic grayling gene pools, although it also seems that panmixia between the founding populations has not yet been reached.

As inferred from the CA and the individual admixture analyses, grayling from the Soča river system consist of several overlapping categories, that is, 'pure' Adriatic grayling, 'pure' introduced grayling of Danubian origin and an array of hybrids, exhibiting various levels of introgression. In fact, the majority of individuals appear to be introgressed and there are very few remaining nonintrogressed indigenous Adriatic grayling. In contrast, the high $F_{\text {is }}$ values observed in the Soča river system samples suggest that there are still some reproductive barriers between the two forms, for example, assortative mating, or that there is some selection acting against heterozygotes. It is possible that the $F_{\text {is }}$ values simply reflect the presence of a few recently stocked individuals, which are of course non-introgressed, thereby creating a slight but significant Wahlund effect. This explanation would seem to be most valid for the River Soča-main basin subpopulation, where the individual admixture coefficients suggested that three individuals could be of pure Danubian origin (Figure 3a).

Koskinen et al (2002a) studied the genetic impact of stocking grayling into Finnish grayling populations, but in this case, the stocked individuals exhibited poor survival and reproductive success compared to indigenous grayling, and the extent of introgression was limited. It is puzzling that these two instances of stocking have led to such different outcomes, but the apparent unpredictability of the genetic impact of stocking activity seems to be a common feature, as evidenced by the many examples summarised by Hindar et al (1991). One important factor is presumably the immigration rate by stocked fish (ie the number of stocked individuals relative to the indigenous population size), and another factor is the selection acting against the stocked fish. However, in order to estimate the immigration rate, detailed information is required on both the number of stocked fish and the size of the indigenous population, and such information is often difficult to obtain, particularly in a case like the Soča river system, where stocking has been ongoing for decades. Also, estimating the selection acting against stocked fish and hybrids is complicated, but grayling in the Soča drainage might in fact provide a good opportunity for future research into this aspect, due to the relative ease of identifying both hybrids and pure individuals using individual admixture analysis.

The population level admixture coefficients were very similar among the three geographically remote populations sampled in the Soča river system, indicating that they are all introgressed to approximately the same extent. The high values of population admixture coefficients (ie $40-50 \%$ of the gene pools were derived from stocked Danubian strain) indicated that the majority of the indigenous gene pools have already been considerably affected. However, the relatively high number of diagnostic alleles characterising the Adriatic grayling and, in particular, the use of individual admixture analysis for distinguishing between the Danubian population of grayling and introgressed and non-introgressed Adriatic grayling may provide a valuable tool for future rehabilitation of populations. Thus, non-introgressed individuals could be identified for supportive breeding programmes that could ultimately reverse the introgression that has taken place so far.

\section{Conservation priorities}

Previous results, along with the results presented in this paper, clearly demonstrate that the Adriatic grayling differs from introduced grayling of Danubian origin both genetically (Sušnik et al, 2001) and morphologically (Janković, 1960). As inferred from mtDNA analysis (Sušnik et al, 2001), the Adriatic grayling must be considered an evolutionary distinctive population group with highly restricted gene flow from other lineages within the grayling species, justifying recognition as an evolutionary significant unit (ESU (Waples, 1995); reviewed by Fraser and Bernatchez, 2001). However, due 
to the introduction of allochthonous populations, the status of the Adriatic grayling has obviously changed. It no longer represents a reproductively isolated unit, but rather an assemblage of individuals exhibiting various degrees of introgression. Allendorf et al (2001) discussed the conservation status of hybridised populations and distinguished between different scenarios. The Adriatic grayling clearly fall into their category 5, where humaninduced hybridisation has led to widespread introgression. In this case, the recommendation is to focus conservation efforts on maintaining and expanding remaining non-introgressed population segments. On the scale of the whole distributional range of the Adriatic grayling, this means that any non-introgressed populations should have a high priority for conservation. However, there are also strong arguments in favour of granting high protective status to the introgressed Soča populations, as introgression is not complete and as it is still possible to identify non-introgressed individuals using microsatellite analysis. However, initiation of such a conservation programme is urgent, as there are only a minority of non-introgressed individuals left, and just a few more spawning seasons may be sufficient to eliminate the last 'pure' Adriatic grayling within the populations.

\section{Acknowledgements}

The research was supported by the Ministry of Science and Technology of the Republic of Slovenia (Grant No. J4-559-402). We are very grateful for the technical expertise provided by D Jesenšek and S Pleško during the sampling campaigns. We also thank $S$ Trasforini for providing samples of $T$. thymallus from River Sessia.

\section{References}

Allendorf FW, Leary RF, Spruell P, Wenburg JK (2001). The problems with hybrids: setting conservation guidelines. Trends Ecol Evol 16: 613-622.

Belkhir K, Borsa P (1998). GENETIX, logiciel sous WindowsTM pour la génétique des populations http://www.univmontp2.fr/ genetix/genetix.htm, Laboratoire Génome et Populations, CNRS UPR 9060, Université Montpellier II, Montpellier, France.

Berrebi P, Povz M, Jesensek D, Cattaneo-Berrebi G, Crivelli AJ (2000). The genetic diversity of native, stocked and hybrid populations of marble trout in the Soča river, Slovenia. Heredity 85: 277-287.

Bertok M, Budihna N (1999). Annual report of Fish Cadastral Register for year 1997. Fisheries Research Institut, Ljubljana, Slovenia.

Bouvet Y, Soewardi K, Pattee E (1990). Genetic divergence within natural populations of grayling (Thymallus thymallus) from two French river systems. Arch Hydrobiol 119: 89-101.

Broughton R (2000). The Complete Book of the Grayling. Robert Hale: London.

Eppe R (2001). Structuration génétique des populations de poissons d'eau vive: comparaison de l'influence respective de l'hydrographie et des traits biologiques chez l'ombre commun et le chabot. PhD Thesis, Université Lyon 1, 171pp.

Fraser DJ, Bernatchez L (2001). Adaptive evolutionary conservation: towards a unified concept for defining conservation units. Mol Ecol 10: 2741-2752.

Goudet J (2001). FSTAT, a program to estimate and test gene diversities and fixation indices (version 2.9.3). Available at, http://www.unil.ch/izea/softwares/fstat.html.
Gross R, Kühn R, Baars M, Schröder W, Stein H, Rottmann O (2001). Genetic differentiation of European grayling populations across the Main, Danube and Elbe drainages in Bavaria. J Fish Biol 58: 264-280.

Hansen MM (2002). Estimating the long-term effects of stocking domesticated trout into wild brown trout (Salmo trutta) populations: an approach using microsatellite DNA analysis of historical and contemporary samples. Mol Ecol 11: 1003-1015.

Hansen MM, Nielsen EE, Bekkevold D, Mensberg K-LD (2001). Admixture analysis and stocking impact assessment in brown trout (Salmo trutta), estimated with incomplete baseline data. Can J Fish Aquat Sci 58: 1853-1860.

Hindar K, Ryman N, Utter FM (1991). Genetic effects of cultured fish on natural fish populations. Can J Fish Aquat Sci 48: 945-957.

Janković D (1960). Sistematika i ekologija lipljena Jugoslavije. Biološki institut: Beograd.

Koskinen MT, Nilsson J, Veselov AJ, Potutkin AG, Ranta E, Primmer CR (2002b). Microsatellite data resolve phylogeographic patterns in European grayling, Thymallus thymallus, Salmonidae. Heredity 88: 391-402.

Koskinen MT, Piironen J, Primmer CR (2002a). Genetic assessment of spatiotemporal evolutionary relationships and stocking effects in grayling (Thymallus thymallus, Salmonidae). Ecol Lett 5: 193-205.

Leary RF, Allendorf FW, Sage GK (1995). Hybridization and introgression between introduced and native fish. Am Fish Soc Symp 15: 91-101.

Medrano FJ, Aasen E, Sharrow L (1990). DNA extraction from nucleated red blood cells. Biotechniques 8: 43.

Meldgaard T, Nielsen EE, Loeschcke V (2003). Fragmentation by weirs in a riverine system: a study of genetic variation in time and space among populations of European grayling (Thymallus thymallus) in a Danish river system. Conserv Genet 14: 735-747.

Nielsen EE, Hansen MM, Bach L (2001). Looking for a needle in a haystack: discovery of indigenous salmon in heavily stocked populations. Conserv Genet 2: 219-232.

Northcote TG (1995). Comparative biology and management of Arctic and European grayling (Salmonidae, Thymallus). Rev Fish Biol Fisher 5: 141-194.

Persat H (1996). Threatened populations and conservation of the European grayling Thymallus thymallus (L., 1758). In: Kirchhofer A, Hefti D (eds) Conservation of Endangered Freshwater Fish in Europe. Birkhauser Verlag: Basel, Switzerland, pp 233-247.

Persat H, Eppe R (1997). Alevinage, pollution et cloisonnement de l'espace fluvial dans les structures génétiques des populations de poisson: l'ombre commun, Thymallus thymallus, dans le Rhône au niveau de la Savoie. Bull Français Pêche Piscic 344/345: 287-299.

Poteaux C, Bonhomme F, Berrebi P (1999). Microsatellite polymorphism and genetic impact of restocking in Mediterranean brown trout (Salmo trutta L.). Heredity $\mathbf{8 2}$ 645-653.

Pritchard JK, Stephens M, Donnely P (2000). Inference of population structure using multilocus genotype data. GenetiCs 155: 945-959.

Rice WR (1989). Analysing tables of statistical tests. Evolution 43 223-225.

Sabbadini A (2000). On Italian and Balkan Grayling. In: Broughton R (ed) The Complete Book of the Grayling. Robert Hale: London.

Snoj A, Sušnik S, Pohar J, Dovč P (1999). The first microsatellite marker (BFRO 004) for grayling, informative for its Adriatic population. Anim Genet 30: 74-75.

Surre C, Persat H, Gaillarrd JM (1986). A biometric study of three populations of the European grayling, Thymallus thymallus (L.) from the French Jura mountains. Can J Zool 64: 2430-2438. 
Sušnik S, Snoj A, Dovč P (1999a). Microsatellites in grayling (Thymallus thymallus): comparison of two geographically remote populations from the Danubian and Adriatic river basin in Slovenia. Mol Ecol 8: 1756-1758.

Sušnik S, Snoj A, Dovč P (1999b). A new set of microsatellite markers for grayling: BFRO014, BFRO015, BFRO016, BFRO017 and BFRO018. Anim Genet 30: 478.

Sušnik S, Snoj A, Dovč P (2001). Evolutionary distinctness of grayling (Thymallus thymallus) inhabiting the Adriatic river system, as based on mtDNA variation. Biol J Linn Soc 74: 375-385.

Sušnik S, Snoj A, Jesenšek D, Dovč P (2000). Microsatellite DNA markers (BFRO010 and BFRO011) for grayling. J Anim Sci 78: 488-489.

Uiblein F, Jagsch A, Honsig-Erlenburg W, Weiss S (2001). Status, habitat use, and vulnerability of the European grayling in Austrian waters. J Fish Biol 59(Suppl A): 223-247.
Voljč B, Ocvirk J (1982). Endemiène sladkovodne ribje vrste v jadranskih pritokih (2). Ribiè 7-8: 211-213.

Waples RS (1995). Evolutionary significant units and the conservation of biological diversity under the Endangered Species Act. In: Nielsen JL Powers GA (eds) Evolution and the Aquatic Ecosystem: Defining Unique Units in Population Conservation Symposium 17. American Fisheries Society: Bethesda, MD, pp 8-27.

Weir BS, Cockerham CC (1984). Estimating F-statistics for the analysis of population structure. Evolution 38: 1358-1370.

Weiss S, Persat H, Eppe R, Schlötterer C, Uiblein F (2002). Complex pattern of colonization and refugia revealed for European grayling Thymallus thymallus, based on complete sequencing of the mitochondrial DNA control region. Mol Ecol 11: 1393-1407. 